JURNAL SENI MUSIK

\title{
E-LEARNING GAMELAN ENSEMBLE PLAYING TECHNIQUES
}

Nor Azman Mohd Ramli ${ }^{\bowtie 1}$

Fakulti Muzik dan Seni Persembahan, Universiti Pendidikan Sultan Idris (UPSI), Tanjung Malim, 35900, Malaysia

Chamil Arkhasa Nikko Mazlan ${ }^{\bowtie 2}$

Fakulti Muzik dan Seni Persembahan, Universiti Pendidikan Sultan Idris (UPSI), Tanjung Malim, 35900, Malaysia

\section{Mohd Hassan Abdullah}

Fakulti Muzik dan Seni Persembahan, Universiti Pendidikan Sultan Idris (UPSI), Tanjung Malim, 35900, Malaysia

\section{Aiman Ikram Uyub}

Fakulti Muzik dan Seni Persembahan, Universiti Pendidikan Sultan Idris (UPSI), Tanjung Malim, 35900, Malaysia

\section{Article Info \\ Submitted : January, 2021 \\ Revised : March, 2021 \\ Accepted : April, 2021 \\ Keywords: \\ E-Gamelan, Pendidikan \\ muzik, Google Classroom, \\ Ensembel Gamelan, \\ Instrumental Learning}

\begin{abstract}
2020 is a very challenging year because of the covid-19 pandemic and this completely changed the music education landscape. In the past, learning musical instruments could be done face to face, now it is impossible. If no action is taken, this situation could cause stress among students, especially those who learning gamelan ensemble instruments. Unlike other musical instruments, the ensemble gamelan is expensive and student cant afford to buy it. That is why set of gamelan is only owned by the university and placed in the faculty only. Due to this, students who live far away are unable to practice their gamelan instrument due to movement control order these days. Therefore, this study introduces Gamelan E-Learning Techniques, which is the concept of learning gamelan basic hand techniques using a simulation methods for keromong, gambang, saron and gendang. The uniqueness of this study is due to the emphasis on the basic hand techniques of gamelan. By using google class application as well, lecturers can upload learning videos as well as assessment of student game techniques online can be done. This study uses experimental case study method with qualitative approach. The participants consisted of second semester of 36 students who attended the AME 3082 gamelan course at Universiti Pendidikan Sultan Idris (UPSI).
\end{abstract}




\section{Nor Azman Mohd Ramli/JURNAL SENI MUSIK (10) (1)}

\section{INTRODUCTIONS}

In the year of 2020 , the whole world strike with the pandemic of corona virus. Due to this, the nature on how we normally live our life has changed, from business sector, other services and even education sector. In order to stop Covid19 spreading, government in the whole world implementing movement control order and any outdoor activity is restricted with standard operation procedure. Thus, the landscape of education in the whole world changed (Culp \& Roberts, 2020), using online learning strategy for all students from primary, secondary and tertiary level of education. Although online learning have many to offer, but not in music education field, especially instrumental education like Gamelan ensemble.

Gamelan ensemble is one of the popular music ensemble around the globe (Widhyatama, 2012). But, learning Malay Gamelan ensemble is not the same like learning other modern instrument such as guitar, piano or even violin. Students who taking Malay Gamelan as their instrumental study need to learn more than one instrument. In Malaysia, Malay Gamelan ensembel consist of nine different instrument, bonang or keromong, gambang kayu, saron peking, saron baron, saron demung, kenong, slentem, gong (agung, suwukan, kempul) and gendang (Wong, 2016). Another reason that learning Gamelan online is not plausible because students can not afford to buy a set of Malay Gamelan because it is very expensive. That is why, Malay Gamelan ensemble music instrument only owned by the university. However, because of movement control order, all teaching and learning activities in Malaysia changed to online and every students required to stay at home, only essentials support services openly in campus.

Not just students can not come to campus for practice due to movement control order, another issues arise in the context of contents for Malay Gamelan learning materials. Although there are some Gamelan application available for download in google playstore, but most of the applications are not suitable for learning Gamelan playing techniques. It is because in Malaysia, students taking Gamelan as their major instrument studies are expose to Malay Gamelan, not Java Gamelan. For example, an application developed by Trimatra Studio, Gamelanku, are focused on Gamelan Sunda (Trimatra, 2021). There are also report stated that the numbering format for bonang instruments are incorrect, which number 4 does not exist in the real bonang notation (Ahmad Aiman, 2020; Siti Fatimah, 2021).
Apart from this, learning Gamelan using application that found in google playstore do not help students to learn basic playing technique properly. All the available application for Gamelan in google playstore do not focusing on how to play the right playing techniques for each instruments in Gamelan ensemble. In this article, we would like to share the idea of how to teach Malaysian Gamelan students a correct way of learning basic playing technique for keromong, gambang, saron and gendang online using google classroom platform.

\section{METHODS}

This study examines the approach of teaching and learning of gamelan playing technique through the online platform of google classroom. This platform was chosen as the main method due to it accessibility for students to submit their assessments as well as it also equipped with an aid to detect plagiarism (Bhat et al. 2018). Based on previous studies, results reported that the used of google classroom platform has shown positive responds among students (Azhar \& Iqbal, 2018), and also academicians (Woudenberg, 2016). This study will be conducted in qualitative method.

The design of this study will be in an experimental case study of qualitative method by using the approach of documentation analysis and interview. Total of 36 students who are registered for the gamelan class of AME 3082, semester 2 of 2019/2020 session, at Universiti Pendidikan Sultan Idris (UPSI) will be the respondants of this study. Data will be collected through video documentation and interview session with the respondants. The uploaded videos of respondants' gamelan playing technique in the google classroom will be analyse. Interview will also be conducted in order to collect feedback from the respondants on the learning process of the gamelan playing technique.

\section{RESULTS AND DISCUSSION}

\section{E-LEARNING OF GAMELAN PLAYING TECHNIQUES}

To develop E-Learning method of gamelan playing technique, researcher has devided to four main topics, which are:

Table 1. Learning Content of Gamelan Playing Technique

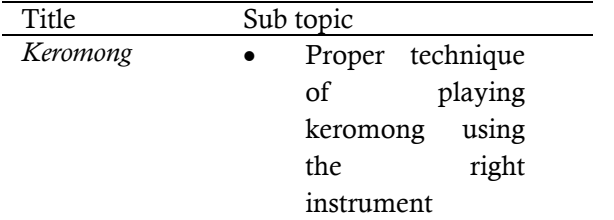




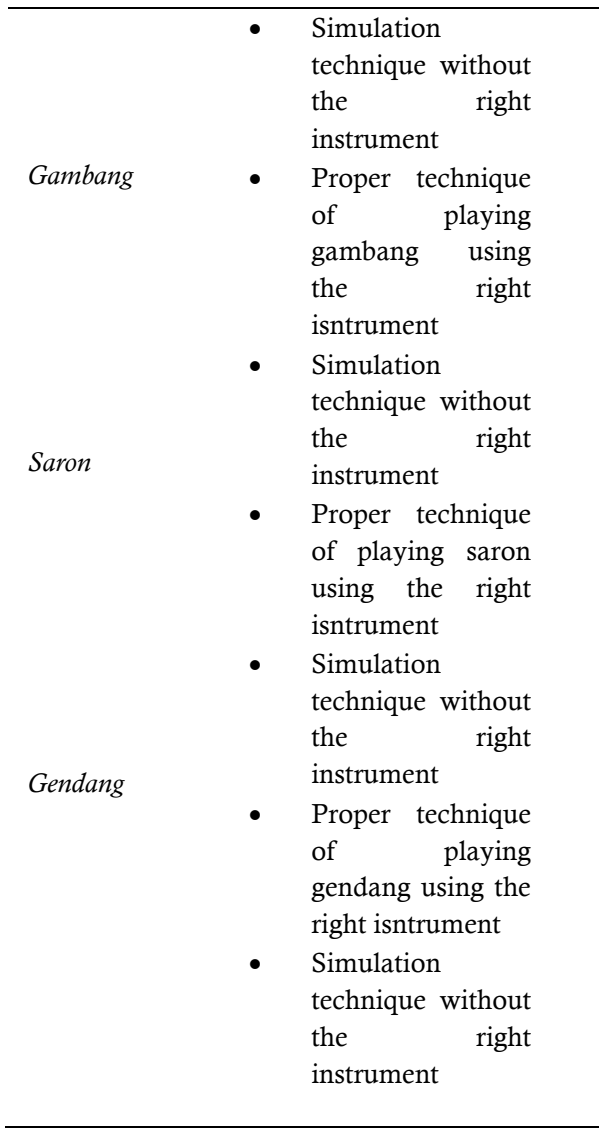

Every titles stated in table 1, will be recorded by the lecturer as the learning content and be uploaded in the google classroom. Student require to download the learning contents in order to learn the basic technique of playing the instrument - keromong, gambang, saron and gendang.

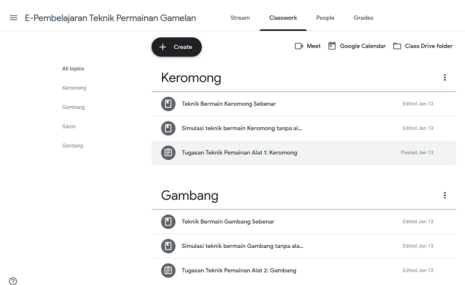

Figure 1. E-Learning Content of Gamelan Instrument Keromong and Gambang in the google classroom

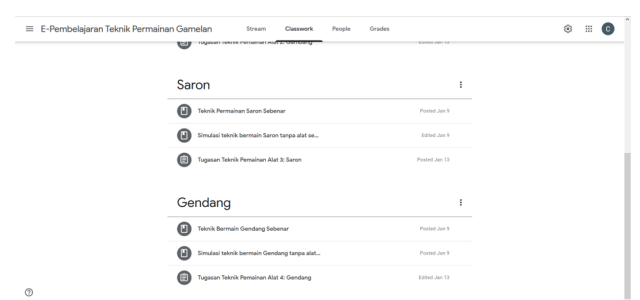

Figure 2. E-Learning Content of Gamelan Instrument Saron and Gendang in the google classroom

\footnotetext{
Learning simulation of playing keromong, gambang, saron and gendang
}

The purpose of this study is to comprehand the learning simulation of gamelan playing technique. With this simulation, students are require to perform the correct technique of gamelan playing by using the instrument, that based on the topic of the recorded video as been mentioned in figure 1 . There will be two recorded videos, which are the video recorded based the technique of gamelan palying on the actual instrument and the simulation gamelan playing technique.

Once the student examine the leaning material (video recorded by the lecturer) students are require to upload (submit) their video of playing the instrument into the google classroom platform as their assessment. Following figure 3, are an example (in picture) of the student performing the simulation approach:

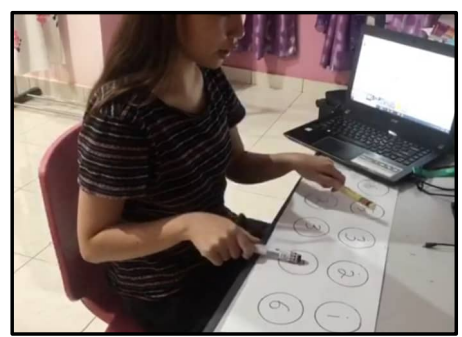

Figure 3. Simulation technique of playing keromong

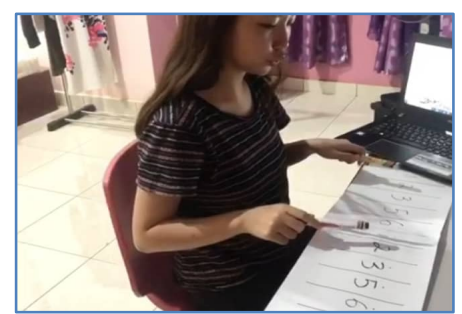

Figure 4. Simulation technique of playing gambang

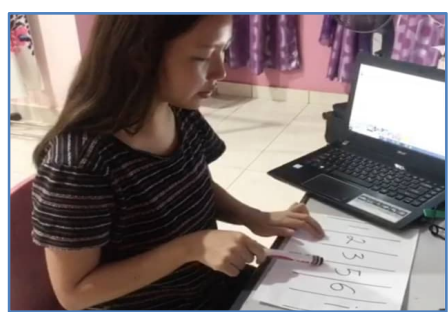

Figure 5. Simulation technique of playing saron

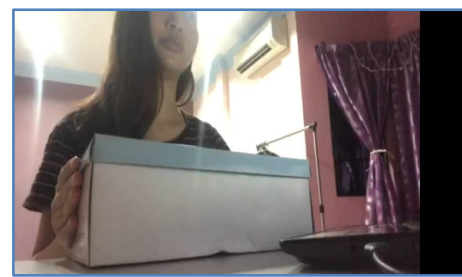

Figure 6. Simulation technique of playing gendang 
Figure 3, figure 4, and figure 5 shows that the simulation approach playing keromong, gambang and saron were performed by using the orgonology of drawing on the paper. While the simulation of gendang playing, figure 6 , was performed by using the shoe box, as the participant require to performed (pronounce) the rhythm of 'Tak' and 'Dung'.

For leaning simulation of this technique, participants will be provided with the audio and music score for every instruments.

\section{CONCLUSION}

Without any doubt, current situation of teaching and learning approach of music education require further development by considering the use of technology as what has been done throughout this study.

This approach of E-Learning technique provides benefit for students who stays in the rural area to access the correct way in learning the technique of gamelan playing. Due to this pandemic of covid19 , the use of blended learning approach are also significance.

By having the E-Learning approach of Gamelan playing technique students can learn such technique via simulation approach. Besides students, google classroom platform has also benefits lecturers to manage and monitor the development of their student in gamelan playing technique.

The implementation on the correct and proper ways of playing a musical instruments are very important, not just for gamelan ensemble but also for others musical instrument. Therefore, the approach of simulation can also be implemented for the others instrumentation especially for those who either have difficulties in owning a personal instrument or issue to be present to the faculty especially during this pandemic.

\section{REFERENCES}

Ahmad Aiman. (Julai 4, 2020). In Gamelanku (Version 1.15) [Mobile application software]. Retrieved from https://play.google.com/store/apps/det ails?id=com.faddensoft.Androidaudioby pass\&reviewId $=\mathrm{gp} \% 3 \mathrm{AAOapTOE}-$ CsNCHcxyl0cerLIDraA7Bso91iL9ofeiDdWaq7Z8UKAi 3upi-a98L2zMt2s43otoFK6Ve7Di-wT

Azhar, K. A., \& Iqbal, N. (2018). Effectiveness of Google Classroom: Teachers' Perceptions. Prizren Social Science Journal, 2(2), 52-66. Retrieved from https://www.prizreniournal.com/index. php/PSSJ/article/view/39

Bhat, S., Raju, R., Bikramjit, A., \& D'Souza, R. (2018). Leveraging E-learning through Google classroom: A usability study. Journal of Engineering Education Transformations, 31(3), 129-135. DOI: 10.16920/jeet/2018/v31i3/120781

Culp, M. E. \& Roberts, R. (2020, Dec 9). Music teaching and learning during covid-19 and beyond. National Association for Music Education (Nafme). https://nafme.org/music-teachinglearning-during-covid-19-beyond/

Trimatra Studio (2021, Januari 8). Trimatra Studio (Version 1.15) [Mobile application software]. Google Play Store. Retrieved from https://play.google.com/store/apps/det ails?id=com.faddensoft. Androidaudioby pass\&reviewId=gp\%3AAOqpTOEz7Di MB3auFICwWD761Xcp3vYfavpiwNN WLuP7KkHeEJMcRv1kOmYghUvEJC YzyrGGkj0U8EWW0yRp

Siti Fatimah. (2021, Januari 5). In Gamelanku (Version 1.15) [Mobile application software]. Retrieved from https://play.google.com/store/apps/det ails?id=com.faddensoft. Androidaudioby pass\&reviewId $=$ gp \%3AAOqpTOEz7Di MB3quFICwWD761Xcp3vYfaypjwNN WLuP7KkHeEJMcRy1kOmYghUvEJC YzyrGGkj0U8EWW0yRp

Widhyatama, S. (2012). Pola Imbal Gamelan Bali Dalam Kelompok Musik Perkusi Cooperland Di Kota Semarang. Jurnal Seni Musik, 1(1). https://doi.org/10.15294/jsm.v1i1.1801

Wong Y.S. (2016). Gamelan Melayu: new instrumentation setip in the ensemble (Master thesis). http://studentsrepo.um.edu.my/6465/1 /viing siing.pdf

Woudenberg, J. (2016, Jan 15). 4 steps to use google classroom in your music class. National Association for Music Education (Nafme). https://nafme.org/4-steps-touse-google-classroom-in-your-musicclass/ 
Nor Azman Mohd Ramli/JURNAL SENI MUSIK (10) (1) 